\title{
English Textbooks Compilation and Innovation from Perspective of Vocational Education Overpass
}

\author{
Bingyan ZHU \\ Department of foreign languages and tourism \\ Hainan College of Software Technology \\ Qionghai, China \\ zhubingyan9@163.com
}

\author{
Shixiang LIU* \\ Department of foreign languages and tourism \\ Hainan College of Software Technology \\ Qionghai, China \\ xiangzi0223@126.com \\ *Corresponding author
}

\begin{abstract}
With the leapfrog development of vocational education in Hainan province, it is necessary to build an overpass between vocational education and higher education. English textbooks play an important role in building vocational education overpass. Based on the teaching curriculum and students' needs analysis in vocational secondary school, it is of great significance to probe into compilation principles and innovation of English textbooks so as to adapt to new teaching methods, develop students' self-leaning habits, improve their spoken and written English, and further their intercultural communication competence, which can make the English textbooks more practical for vocational and higher education.
\end{abstract}

Keywords-vocational education overpass; English textbooks compilation; vocational secondary school; principle and innovation

\section{INTRODUCTION}

On February $26^{\text {th }}, 2014$, Premier Li Keqiang chaired a State Council meeting to accelerate the development of modern vocational education in China. At the meeting, he held that the development of vocational education was to promote the strategic initiatives in changing development mode, restructuring and improving people's living standard, establish credit accumulation and transfer system, and integrate the education system from secondary vocational schools and colleges to universities. In accordance to the basic trend of the development of vocational education, the Education Department of Hainan Province approved three personnel training modes, i.e. Five-year consistent system from secondary vocational schools to colleges, segmented education in secondary vocational schools for 3 years plus 2 years in colleges and segmented education in colleges for 3 years plus 2 years in universities. Therefore, it's necessary to create an education overpass from secondary vocational schools and colleges to universities.

\section{A. The Status quo of English Text-books and Teaching in Secondary Vocational Schools}

The key factor that builds an integrated personnel training system from modern vocational education to higher education lies in the textbooks selection, the content improvement and its practical use. English textbook plays an important role in building vocational education overpass in terms of English teaching. With the development of vocational education, teaching materials have been gradually improved. The adapted materials introduced by foreign authors and the teaching materials compiled by domestic scholars are complement with each other. Meanwhile, English teaching materials in secondary vocational schools have been gradually improved, and the most striking one is adaptation textbook of New Concept Secondary Vocational English published by Shanghai foreign language teaching press in July 2009, according to the Ministry of Education that recently promulgated the secondary vocational school English teaching syllabus. The textbooks are expected to develop students' ability by integrating topics, scenes, tasks and activities, functions, pronunciation and grammar, etc. , whose materials must be new and real, absorbing the strengths of traditional textbooks. Meanwhile, it also focuses on cultivating students' team spirits based on contexts and tasks.

\section{B. The Analysis of Published Vocational English Textbooks}

Meanwhile, domestic scholars have successively compiled and published some English textbooks for vocational colleges: 1) Vocational English Textbooks series written by Luo Renjia in August 2006 published by Chongqing University Press. The contents are very interesting and practical, involving listening, speaking, reading, writing and supplementary readings, and so on, which focuses on developing of students' communicative competence. 2) Vocational Education Planning Textbooks written by Peng Xiangyang and published in September 2007 by Ji Nan University Press. This book highlights the characteristics of classroom teaching in secondary vocational education. It provides a wide range of subjects closely related to students' future career and living environment including self-introduction, hobbies, shopping, restaurants, hospitals, banks, taxi, airport, hotel, tourism, interview, social occasions, thanks, apology, and future plans. 3) The textbook English written by Sun Li and Dan Hanling was published in 2008, which is designed for students in secondary vocational schools. There are twenty units, which cover the topics of entertainment, weather, health, direction, tourism, employment, transportation, environmental protection, energy conservation, television, computer and sports, etc. Each unit consists of four parts, such as listening and speaking, reading comprehension, grammar and exercises, reading and writing. At the same year, New Practical English for secondary vocational school was published by Xi'an Jiao Tong University Press and edited by Huang Tuancai and Wang Qinxiang. The topics of the book are composed of the financial, accounting, gardening, electrical maintenance, 
driving and maintenance, tourism and so on. The contents of this textbook are up-to-date, which attract students' attention, and focuses on developing students' communicative competence and highlights the teaching characteristics in vocational school. It is worth mentioning that the New Century Vocational English series published by Shanghai foreign language education press for the secondary vocational schools in Shanghai. This book can stimulate students' interests to actively participate in listening, speaking, reading and writing practice, according to Shanghai Secondary Vocational School English Curriculum Standards (for trial) and under the theory of task-based teaching method. At the same time, this textbook provides students with more capacity to further expand their knowledge and skills. 4) Vocational English Teaching integrating Doing written by Wang Yanrong and Wang Sanying was published by Huazhong University of Science and Technology Press in August 2013. This book chooses ten topics including greetings, date, hobbies, digital shopping, directions consulting, phone answering, seeing the doctor, weather forecast, and family life. The content of each unit is made up of warming up and lead in, listening and speaking, everyday English, reading and writing, language in use, pronunciation practice, self-check, new words and expressions, English proverbs, and amusement time.

Although the published English textbooks for vocational colleges in terms of teaching objectives, contents and requirements are relatively complete, there are some disadvantages, such as boring contents, and higher language repetition rate, and so on. Therefore, those textbooks can't meet students' needs for the development of communicative competence. What's more, some contents are cut off from students' actual life, without innovation, validity and the sense of the times. Therefore, the secondary vocational students are generally confused with English Learning, which made them refuse to speak English. In summary, the English textbooks for vocational schools and colleges were compiled and published mainly in developed regions. Currently, there are no vocational English textbooks published in Hainan, which are not conducive to constructing vocational education overpass. Compared with the whole country, the overall level of basic English in Hainan is relatively low, and the secondary vocational English is even worse. It is believed that one of the key factors of English teaching in vocational schools is to compile new series of English textbooks for vocational students in Hainan.

\section{LITERATURE REVIEW}

The education overpass refers to the educational transition from secondary schools, vocational colleges to undergraduate based on the regulations and policies of the local and national education institutions with extensive and flexible characteristics of vocational education, aiming to cultivate students' skills in practice. Therefore, students can choose their own development path of education according to their conditions and desires [1]. Mo Zhiming arguing that the vocational schools should take the vocational education itself as the main path, and study the other forms of education development mode so as to broaden the development of vocational education and promote the development of talents. It can be seen that the vocational education overpass should be an organism, through which the secondary vocational schools, colleges, and universities can be coordinated with promotion and balanced development [1]

However, the study on vocational education overpass is still in its initial stage, which mainly includes the following aspects. Firstly, the studies on mode and strategies. Gao Jie believes that lessons should be drawn from the developed countries, with the curriculum taken as the core, to scientifically manage the connection between vocational school and higher education [2]. Shen Lei analyzes the connecting status between secondary and vocational education based on the data of enrollment, and then proposes the strategies of standardizing management system of vocational education and optimizing credit system, etc. [3]. Tang Shuling and Zhang Dongyun analyze the current situation of higher vocational education system in Tangshan City, then put forward the construction of Higher Vocational Education overpass. They emphasize the importance of government's leading role and the integration of education resources and industry associations [4]. Secondly, introduction to the practice and successful experience in building vocational education overpass. For example, Xie Hong and Lv Hong introduce the modern vocational education system framework in Chongqing and its important measures, such as adjusting and optimizing professional layout, the reform of enrollment examination system, innovation of management mechanism, and improvement of quality evaluation mechanism so as to ensure that the smooth connection between full time and parttime education, non-academic and academic education [5]. Thirdly, enlightenment of foreign vocational education flyover For example, Liu Feng analyzes the successful experience of vocational education overpass in Singapore, such as the introduction of well-known overseas college degree courses in science and engineering, the establishment of a unified system shunt, and implementation of the double track vocational education, credit recognition, diploma and certificate of accommodation, no entrance examination system. At last, the construction of the specific course teaching from the perspective of research based on the vocational education overpass [6]. Guo Li, Wang Wenjin, and Shi Shaobo deeply analyzes the difficulties in the study of College Physics by comparing the differences of intelligence and ability between the secondary vocational school graduates and ordinary high school students to build an appropriate teaching mode for college students from secondary school [7].

The construction of Hainan vocational education overpass is only in the pilot phase of the project, and a series of problems, such as how to solve the problems of English training, curriculum system, assessment and evaluation of the vocational education overpass, will be the bottleneck of the construction of Hainan vocational education overpass.

\section{TEXTBOOKS COMPILATION AND INNOVATION}

When compiling secondary vocational English textbook, we should take students' campus life, daily activities and future career into consideration. It's necessary to improve contents of textbook and design more practical teaching materials which are close to students' life and future career. Therefore, it should transfer the teaching modes from teacher- 
centered to students-centered. What's more, building vocational education overpass should focus on cultivating students' intercultural communicative competence, which should adhere to the principles with some innovations:

\section{A. Meeting Learner' needs}

Needs Analysis, which is a research method through introspection, interview, observation and questionnaire to study needs, is widely used in foreign language teaching. Generally speaking, there are two goals for foreign language learners' needs analysis. One is to design a new curriculum system, and the other is to optimize the existing curriculum system [8]. Hutchinson and Waters believe that learners' needs can be divided into learning needs and target needs. Learning needs mainly refers to the learner's learning motivation, expectations and learning conditions, etc. Target needs refer to knowledge and skills for the future career someone must grasp [9]. Yang Jinrui and Ding Jing believes that the target analysis actually is a kind of social needs, which refers to employer's needs for their future employees [10]. Dudley-Evans and St. John hold that it is necessary to take the following factors into account while doing students' needs analysis, such as learners' present language level, the level learners want to achieve, the task and activities that the learners can accomplish, what the learners want to study, how to make the leaner master and use appropriate language and techniques to express their ideas, the factors that influence learners in their study, and the effective ways to make up for the gap [11].

According to the vocational students' age and psychological characteristics, the topics of the textbook should select some popular interesting themes, such as festivals, travel, food, shopping, music, movies and digital devices which are more likely to arouse students' interests of learning English and make much more improvement. The contents of the material selection must be based on the students' interests, taking their daily life and future careers into account. On the other hand, the contents must be arranged properly, which is easier for students to build their confidence. Meanwhile, it needs to encourage vocational students to grasp the basic English writings according to the specific learning or career situation, such as expressing greeting, gratitude, apology, and business cards, personal resume gradually from simple sentences to longer paragraphs.

\section{B. Selecting Real Context for Practice}

Whether vocational English textbooks can provide real scenes and activities or not affects the practicality of the textbook and the improvement of students' practical ability. Validity not only refers to the authenticity of the tasks, but also includes the circumstance, and the roles that students can be immersed into the activities. Wang Yan believes that the validity of teaching materials includes in the following aspects. First of all, it's the validity of the training objectives. Students' future career requires that they must master fluent language expression skills, such as self-introduction, sending cards or giving gifts, business negotiation, and filling in different kinds of forms. Secondly, the contents must be true and up-to-date. The content of textbooks should be authentic, new and expressed in native speakers' way, such as oral
English, listening materials, writing styles, the methods of translation, and so on [12]. Therefore, students must be familiar with the native expressions so that they can improve their language level faster, and enhance their social and cultural understanding of the relevant countries more efficient. Last but not the least; the tasks must be true in real life. The real task refers to the daily activities in communication, such as practical writing, participating in the birthday party, seeing the doctor, withdrawing money from the bank, watching movies in the cinema, etc. The integration of training tasks, students' practical learning, and communicative motivation can arouse students' interest in English learning and promote their communicative competence. What's more, in order to ensure the validity of the task, the rationality of the content arrangement, the up-to-date features, and the quality teaching resources, the compilation of vocational English textbook adheres to the some principles, with practical value oriented, step by step so as to integrating vocational education and higher education for more talents cultivating.

It is believed that the topics of listening and speaking should be based on students' interests, and content selection should be close to their campus and daily life, such as the first time students meet the teacher or students each other, dining out, shopping, birthday party, and so on, which can narrow the distance between students and the textbook. And students can easily participate in discussing the topic and help them solve problems in daily life and future career, and promote their cross-cultural communication competence.

\section{Arranging Tasks in Order of Difficulty}

According to the vocational students' characteristics, cognitive ability and learning strategies, the situation tasks assigned in certain contexts should be gradual, following the principles whether they can be adaptable, absorbed and adorable. On the one hand, situation tasks should not be too easy and repeat the contents of English in junior middle schools, which may make students easily feel bored and refuse to study the same things. On the other hand, the contents can't be too complex or difficult in case they are discouraged. It must make sure that students in higher vocational schools and colleges are full of confidence on the project training. Corder holds that students can't be made to adapt to the teaching materials and teachers. Instead, teaching materials and teachers should be adjusted to the students [13]. Taking the Practical Vocational English edited by the author as an example, the contents of the textbook compilation start from on-campus and off-campus life about college students, including a series of popular topics, such as self-introduction, hobbies, birthday party, dining, festivals, shopping, seeing the doctor, vacations, and other scenario. The situation tasks are arranged as gradually as possible. In addition to language input, this book also emphasizes promoting students' intercultural ability, introducing the some differences between Chinese and Western cultures, such as the customs of giving gifts and the meaning of different festivals, and different ways to see a doctor and the different connotations of the numbers, etc. Meanwhile, it helps students to better understand the cultural background of the British and American countries so as to improve their English language ability and intercultural competence. 


\section{Making Full Use of Information Technologies}

With the internationalization of higher education and the rapid development of economic globalization, the English teaching materials in vocational schools should adhere to the principle of combining traditional and modern information technology so as to meet students' personalized, cooperative or blended learning. First of all, we should actively study and introduce foreign English textbooks, electronic courseware, autonomous training network resources, teaching outlines and lecture sheets, and so on from developed countries or regions to accelerate the trend of internationalization and promote students' independence and ability to apply English to practice. According to the characteristics of Chinese vocational students, the textbook New Concept of Vocational English adapted by Shanghai foreign language teaching press effectively cultivates students' ability of cooperation and innovation based on the vocational students' real campus life and future career situations with the help of integration of modern information technology. At the same time, it provides a wealth of supporting teaching resources, such as multimedia teaching course-ware, network autonomous learning resource and explores the characteristics of Chinese vocational students to edit three-dimensional teaching material.

Secondly, it is of great value to combine the traditional teaching with modern information technology through comprehensive utilization of the school autonomous learning platform, the network interactive teaching platform, English forum. Last but not the least, it is necessary to maintain the sustainable development of English teaching in vocational schools and colleges with integration of videos, audios, pictures, texts and other multimode based on modern information technology and three-dimensional training.

In addition, the students in secondary vocational are averagely at 15 or 16 years old. As a freshman, their mental development is not mature, so it is indispensable to strengthen their ideological, metal and moral education. A set of high quality vocational English teaching materials should penetrate correct attitudes towards study, life and world to better cultivate students' professional ethics and improve their humanistic quality through the power of language.

\section{CONCLUSION}

With the internationalization of higher education and the rapid development of economic globalization, the English teaching materials should meet students' needs in vocational schools or secondary vocational colleges. Zhuang Zhixiang expects to establish a scientific and comprehensive framework for evaluating China's foreign language textbooks to make the foreign language textbooks with Chinese characteristics [14]. This paper analyzes the status quo of published English textbooks and teaching in secondary vocational schools and colleges, and summarizes the main problems based on the literature review of Hainan vocational education overpass. Then the strategies for English textbooks compilation and innovation in secondary vocational schools are summarized as following, such as meeting learner's needs, selecting real context for practice, arranging tasks in order of difficulty, and making full use of information technologies to meet the needs of the post-1990s who can have access to knowledge at any place and time in the context of M-learning[15].

\section{REFERENCES}

[1] Mo Zhiming, "The Construction and Development of Vocational Education Overpass in China," Vocational and Technical Education Forum, vol. 2, pp. 61-65, JAN. 2014.

[2] Gao Jie, “The Problems of Building Vocational Education Overpass, Continuing Education,” vol. 6, pp.9-11, June 2013.

[3] Chen Lei, "On building Higher Vocational Education Overpass in Xinjiang, Education and Vocation,” vol. 5, pp.7-9, March 2013.

[4] Tang Shuling and Zhang Dongyun, "The Construction of Higher Vocational Education Overpass in Tangshan City,”Education and Vocation, vol. 8, pp.25-26, April 2013.

[5] Xie Hong and lv Hong. "The Construction of Modern Vocational Education System and the development of Technical Talents, Chinese Vocational and Technical Education,” vol. 3, pp.25-31, JAN. 2013.

[6] Liu Feng, "The Implication of Vocational Education System in Singapore Over pass Style,” Vocational and Technical Education, vol. 5, pp.117-118, May 2011.

[7] Guo Li, Wang Wenjin and Shi Shaobo, "The Construction of Vocational Education Overpass from College Physics,” Vocational and Technical Education Forum, vol. 15, pp.1-3, May 2010.

[8] Su Wei, "A Survey on the Needs of Interpretation Course from Learner's Perspective, Foreign Language World,” vol.5, pp.84-92, May 2011.

[9] Hutchinson, T. and A. Waters, English for Specific Purpose. Cambridge: Cambridge University Press, 1987.

[10] Yang Jinrui and Ding Jing, “A Needs Analysis Based Survey of the Curriculum Design for Undergraduate Translation Majors,” Shan Dong Foreign Language Teaching Journal, vol.5, pp.74-82, OCT. 2013.

[11] Dudley-Evans, T. and St. John, Development in English for Specific Purposes, Cambridge: Cambridge University Press, 1998.

[12] Wang Yan, "On the Principles of Compiling English as Special Purpose,” Foreign Languages in China, vol.5, pp.75-81, April 2011.

[13] Corder, S.P. Error Analysis and Interlanguage. Oxford: Oxford University Press, 1981.

[14] Zhuang Zhixiang, "On Foreign Language Textbooks Compilation and Evaluation Framework with Chinese Characteristics,” Foreign Language World, vol.116, pp.49-56, DEC. 2006.

[15] Shixiang Liu and Bingyan Zhu, “On EFL Teachers' New Roles in Elearning," in Advances in Social Science Education and Humanities Research, vol. 28, Xiaonan Xiao, Ed. Paris: Atlantis Press, 2015, pp. 9396. 